\title{
Determination of Some Physical Properties of Rapeseed
}

\author{
Mehmet Firat Baran**, Mehmet Recai Durgut**, Turkan Aktas**, \\ Poyraz Ulger**, Birol Kayisoglu** \\ *University of Adiyaman, Faculty of Technology, Energy Systems Engineering, 02040 Adiyaman, Turkey. \\ **University of Namık Kemal, Faculty of Agriculture, Biosystems Engineering, 59100 Tekirdağ, Turkey. \\ (mbaran@adiyaman.edu.tr,mrdurgut@hotmail.com, taktas@nku.edu.tr,pulger@nku.edu.tr, bkayisoglu@nku.edu.tr)
}

${ }^{\ddagger}$ Corresponding author: Mehmet Firat Baran, University of Adiyaman, Faculty of Technology, Energy Systems Engineering,
02040 Adiyaman, Turkey, Tel: +90 41622338 00, Fax: +90 41622317 74, mbaran@adiyaman.edu.tr

Received: 06.04.2016 Accepted: 12.06 .2016

\begin{abstract}
Rapeseeds (Brassica napus oleifera L.) were analyzed for some physical properties production in Kurklareli province. Also some physical properties of rapeseed such as seed moisture content, length, diameter, mass of single seed, thousand seed mass, geometric mean diameter, sphericity, seed volume, density, accumulation angle and friction coefficient have been determined. Kernel moisture, thousand kernel mass, plant length, plant stem diameter, yield of the harvested crop were determined as $8.34 \%, 4.74 \mathrm{~g}, 158.2 \mathrm{~cm}, 8.10 \mathrm{~mm}, 3204 \mathrm{~kg} / \mathrm{ha}$, respectively. Length, diameter, mass of single kernel, geometric mean diameter, sphericity, bulk density, accumulation angle and friction coefficient were found as $2.35 \mathrm{~mm}, 1.93$ $\mathrm{mm}, 0.0047 \mathrm{~g}, 2.07 \mathrm{~mm}, 0.88,5.07 \mathrm{~mm}^{3}, 617 \mathrm{~kg} / \mathrm{m}^{3}, 29^{0}, 0.318$ (on galvanized sheet), 0.288 (stainless steel), 0.305 (aluminium), respectively.
\end{abstract}

Keywords: Rapeseed, physical properties, plant properties, seed properties

\section{Introduction}

As a of source vegetable oil, canola is a valuable oil crop plant, in fact the second highest produced in the world, following soya. In 2008, 57.86 million tons of canola seeds have been produced in the world in a total area of 30.30 million ha, while out of the approximate 392 million tons of the global vegetable oil production, 57.86 million tonnes have been met from canola [1]. China, Germany, India, Poland, England, France and Canada, in particular, are the most prominent canola oil producers and consumers in the world. In Turkey, canola farming started after World War II by the Bulgarian and Romanian immigrants in Thrace Region and over time it spread to other regions and by 1979 it reached an area of 27 thousand ha. However, after that date use of rapeseed varieties have been prohibited on the grounds that they contain high levels of fatty erucic acid and by 1985 , it's farming was reduced to 100 ha. However, after the introduction of 00-type rapeseed varieties (canola) not containing fatty erucic acid and glucosinolate, it has become to be reproduced, particularly in Cukurova and Thrace regions [2].
In Turkey, the amount of successfully planted oil crop plants in winter conditions, such as canola, is highly limited. Canola farming displays significant similarities with wheat growing techniques, and they are being planted and harvested almost within the same time period (September-July). Therefore, particularly in dry farming areas with heavy cereal production, it becomes crucial as an alternative to cereals. When rosette leaves have already blossomed before winter months, certain aspects of canola, such as being highly durable against colds, not requiring any additional irrigation other than natural precipitation, reaching harvest maturity by July at the latest, being easily harvestable by a combined harvester and yielding more products, on average $30.1 \mathrm{~kg} / \mathrm{ha}$, than grains in dry farming conditions [3] makes canola indispensable. Oils containing high levels of erucic acid are harmful for human health, and similarly, cossets containing high levels of glucosinolate are harmful for animal health [4,5]. Therefore, rapeseed varieties which do not contain erucic acid in their oil, and those not containing glucosinolate in their cossets have been improved [6,7]. In modern times, 00 type rapeseed varieties containing low levels of (>2\%) erucic acid (C22.1) in oil and low levels of $(>30 \mu \mathrm{mol} / \mathrm{g})$ glucosinolate in cossets are called canola $[7,8]$. 


\section{INTERNATIONAL JOURNAL Of ENGINEERING TECHNOLOGIES}

\section{Mehmet Firat Baran et al., Vol.2, No.2, 2016}

Canola oil contains $65 \%$ oleic, $\% 20$ linoleic, $9 \%$ linolenic, $4 \%$ palmitic and $2 \%$ stearic acids on average $[7,9]$. Thus, containing over $60 \%$ oleic acid, canola oil differs from other vegetable oils (such as sunflower, soya, corn oils) while displaying similarities with olive oil [7].

It is possible to examine the physical characteristics of agricultural products by taking the single unit of each product variety or bulk stocking type as a basis. The important thing here is to correctly define and present the engineering parameters such as the product's shape, size, volume density and surface area. [10].

Physical characteristics are highly important in terms of sowing equipment, harvesting, handling, stocking and processing of the canola seed [11]. For the designation of granaries, silos and agricultural machinery, the friction coefficients of the agricultural products on various surfaces are needed. When designing granaries and silos, friction coefficient is used to calculate the vertical load on the membranes. In pneumatic transmission, particularly in high product concentrations, product-membrane friction creates an important resistance force. Flowing characteristics of granulated products are related to friction coefficients. Friction contributes to cutting, meshing and pressing of agricultural products. The movement of a granulated product on a rotating disc is affected by friction.

All these examples indicate that friction is present in almost all agricultural acts and is not to be ignored [10].

There have been a number of studies performed with the purpose of determining the productivity and physical characteristics of canola seed.

Çalışır et $\mathrm{al}^{[11]}$ reported that, 2005, have analysed certain physical characteristics (size, length, diameter, geometric average diameter, roundness, mass of single seed, 1000 seed mass, volume density, final velocity, surface area and porosity) of canola seeds at three different moisture content levels $(4.7 \%, 13.14 \%, 23.96 \%)$. The results have been listed as; $2.07-2.29 \mathrm{~mm}, 1,84-1.99 \mathrm{~mm}$, 1.91-2.08 mm, 0,93-0.91, 0,0040-0,0065 g, 5,10-6,36g, $3,96-5,15 \mathrm{~mm}^{3}, 612,1-585,1 \mathrm{~kg} / \mathrm{m}^{3}, 3,16-3,74 \mathrm{~m} / \mathrm{s}, 3,71-$ $4,67 \mathrm{~mm}^{2}, 48,2 \%-60,6 \%$ respectively. The study has concluded that all the dimensions of the canola seed has increased with an increase in porosity, surface area, 1000 seed mass and final velocity, moisture content; volume density and roundness has been reduced with an increase in moisture content; while static and dynamic friction coefficient characteristics have increased when moisture content was increased.

İzli et al. ${ }^{[12]}$ reported that, 2009, have analysed some physical and mechanic characteristics such as size, length, diameter, geometric average diameter, sphericity, 1000 seed mass, surface area, volume density, porosity, final velocity and friction coefficient of three different canola seeds in two different moisture content levels $(8,3 \%$ $25,9 \%, 7,7 \%-27,4 \%, 7,3 \%-26,4 \%)$ for each seed. The results acquired were as follows; size $2,26-2,54 \mathrm{~mm}$, diameter 1,85-2,08mm, geometric diameter 1,96-2,23 mm, sphericity $86,1 \%-89,8 \%$, surface area $12,1-15,7 \mathrm{~mm}^{2}$, volume value i 4,56-6,60 $\mathrm{mm}^{3}$, accumulation angle $18,22-$ $26,81^{\circ}$, final velocity value $3,44-3,77 \mathrm{~m} / \mathrm{s}$ and friction coefficient $(0,244-0,358$ in galvanized surface, 0,2330,331 in stainless steel surface, and 0,237-0,335 in aluminium surface). In their study, they have determined that the all the porosity, surface area, 1000 seed mass, final velocity and friction coefficient values of canola seed as increased when moisture content was increased, while volume density and roundness values decreased upon a decrease in moisture content.

Hazbavi and Minae ${ }^{[13]}$ reported that 2009, have used standard methods to determine certain physical characteristics such as size, length, diameter, geometric average diameter, sphericity, surface area, volume values and porosity of 7 different canola seeds (Option, Orient, Talaye, Global, Hyola 401, Hyola 308 and Colvert), based on freshness, in 6 different moisture levels $(5,49,4,55$, $5,41,4,74,5,53$ and 5,32). Conclusion of the study has revealed; $1,84-2,30 \mathrm{~mm}, 1,76-2,15 \mathrm{~mm}, 1,59-1,90 \mathrm{~mm}, 1,76-$ 2,09mm, 0,91-0,96, 9,74-13,86 $\mathrm{mm}^{2}, 2,67-6,44 \mathrm{~mm}^{3}$, $928,01-1370 \mathrm{~kg} / \mathrm{m}^{3}, 675,61-741,6 \mathrm{~kg} / \mathrm{m}^{3}, 25,3 \%-45,9 \%$ respectively. They have noticed that certain physical characteristics produce significantly different values based on the canola variety and canola moisture content.

In this study, the object was to determine the agricultural characteristics (plant size, number of side branch and number of carob in the plant, number of grain in carob) of canola plant which has reached harvest moisture, seed yield, as well as the harvest related physical characteristics (moisture content, 1000 seed mass size characteristics, sphericity, mass of single seed, volume mass, accumulation angle and friction coefficient on 3 different surfaces) of the harvested seed. The distinguishing aspect of the study is that not only the seed characteristics of harvest period Elvis variety canola plant have been determined but also the herbal component characteristics have been defined.

\section{Material and Method}

\subsection{Material}

The plant material in the study was Elvis variety winter canola of Brassica Napus L. species. Elvis variety is a fast growing winter canola variety with a strong root and stalk structure, durable against cold, high levels of fat (40-45\%) high hectolitre weight and 00 erucic acid level.

Trials took place at a farmer's land in Ürünlü village of Kurklareli city. The $5^{*} 20 \mathrm{~m}$ trail zone has been divided into three parcels and samples of canola plant have been taken.

The trial zone has been made ready for planning by early September. During the seedbed preparations stage, $20 \mathrm{~kg} / \mathrm{da}$ 20-20-0 composed fertilizer has been broadcasted to the whole trial zone. Planting norm has been applied at a rate of $450 \mathrm{gr} / \mathrm{da}$. No herbicide has been applied but weeds have been removed by the use of a hand hoe. Once the plants have reached the 6 leaf stage, they have been thinned at an interval of $10 \mathrm{~cm}$ rows. During the month of March, 26\% ammonium nitrate fertilizer has been applied at a rate of $25 \mathrm{~kg} / \mathrm{da}$. No irrigation took place. Pesticide has been applied twice in May and June against leaf beetle. Harvesting took place in June. 


\section{INTERNATIONAL JOURNAL Of ENGINEERING TECHNOLOGIES}

\section{Mehmet Firat Baran et al., Vol.2, No.2, 2016}

In addition to the plant material used in the study, a tape line has been used for plant size measurements, a calliper for plant stalk thickness measurement, a micrometre with a precision of $0.01 \mathrm{~mm}$ for the measurement of seed lengths, humectant containers to measure the product moisture content, precision balance and microprocessor controlled thermostat and a timer and dryer (drying oven) with a temperature precision of $+5{ }^{\circ} \mathrm{C}$ $250{ }^{\circ} \mathrm{C}$, as well as 3 friction surfaces, galvanized metal, stainless steel and aluminium, to determine the friction characteristics of the material on different surfaces.

\subsection{Method}

\subsubsection{Determining the Harvest Related Characteristics of Canola Plant}

Depending on the warm or rainy weather conditions and early rising of the variety, canola plant reaches harvest maturity between 40 to 50 days after blossoming. When canola reaches harvest maturity, the stalks, leaves and capsules of the plant completely dry up and turn pale, and a yellow colour occurs. If the seed has turned brown and seed moisture content drops below $10 \%$, it means that it is time to harvest the plant. Maturing in canola plants occurs from bottom to top. Waiting for full maturity in harvesting may lead to cracks and shedding may occur in lower capsules [2].

\subsubsection{Stalk (Trunk) Diameter}

25 samples have been taken from the relevant trial parcel for calculating the plant stalk (trunk) diameter. The samples have been measured by the use of a calliper to define the average stalk (trunk) diameter value.

\subsubsection{Measuring the plant length}

25 samples have been taken from the parcels at the trial zone to measure the plant length. Samples have been cut by scissors right above the soil, and measured by a tape line to define the average plant length values.

\subsubsection{Counting the amount of side branches}

25 sample plants have been taken from all parcels to count the number of side branches and the figures have been divided to the number of samples to define the average number of side branches.

\subsubsection{Counting the number of carob (capsule) in the plant:}

Once the canola flowers are inseminated, the ovarium develops, and fruits in the shape of capsule or carob with approximately 10-26 seeds occur inside, the fruits consist of two sections, divided by a placenta (membrane) [2]. 25 samples have been taken from the parcels at the canola trial zone and the number of carobs per plant has been counted before dividing the total figure to the number of samples to define the average values.

\subsubsection{Counting the number of grains in the carob}

25 samples have been taken from the parcels at the canola trial zone and the number of grains per carob has been calculated, before dividing the total figure to the number of samples to define the average values.

\subsubsection{Defining the field product yields}

In order to define the field yield, samples have been taken from three different parts of the field within a 1 square meter area before harvesting the measured parcels, the samples in this section have been manually harvested, the product has been weighed and average values have been calculated, which have been related to the yield per decare [14].

$\mathrm{Q}_{\mathrm{T}}=\frac{q t}{n}$

In this equation;

$\mathrm{Q}_{\mathrm{T}}$ : Field grain yield $(\mathrm{kg} / \mathrm{da})$

qt : Grain yield total of the samples $\left(\mathrm{gr} / \mathrm{m}^{2}\right)$,

$\mathrm{n}$ : Number of samples taken from the fields.

2.2.2. Defining the Harvest Related Characteristics of Canola Seed

\subsubsection{Defining the seed moisture content}

Harvesting of canola plant takes place when the moisture of the seed is below 8-10\% [15]. In order to confirm whether the product has reached harvest moisture, samples have been taken at certain intervals during the harvest period, and the moisture content of the seed has been defined in conformity to the standards [16]. Seed moisture content has been calculated by using the following equation on the basis of freshness.

$$
N_{y b}=\frac{W_{s}}{W_{s}+W_{m}}
$$

In this equation,

$$
\begin{array}{ll}
\mathrm{N}_{\mathrm{yb}} & \text { : Seed moisture content }(\%), \\
\mathrm{W}_{\mathrm{s}} & \text { : Wet weight of product }(\mathrm{g}), \\
\mathrm{W}_{\mathrm{m}} & \text { : Dry weight of product }(\mathrm{g}) .
\end{array}
$$

\subsubsection{Defining the thousand grain mass}

Certain amounts of samples have been taken from the harvested product to define the thousand grain mass and divided into groups of 100, and these groups of 100 samples have been weighed 4 times. Scale averages of the 100 's groups have been taken and this average has been multiplied by 10 to find out the 1000 seed mass of the product [17].

\subsubsection{Defining the seed lengths}

In order to calculate the seed lengths, 10 sample groups containing 100 seeds have been randomly selected and then their related length, width and diameter values have been measured.

2.2.2.4. Defining the sphericity and geometric average diameter values: 


\section{INTERNATIONAL JOURNAL Of ENGINEERING TECHNOLOGIES}

\section{Mehmet Firat Baran et al., Vol.2, No.2, 2016}

Sphericity value is a scale of the disfigurement of the seed too [18]. Based on the seed length, the sphericity and geometric diameter values of the canola seed have been calculated by using the below equations $[19,20]$.

$\varnothing=\left(\mathrm{L}^{\mathrm{D}} \mathrm{D}^{2}\right)^{1 / 3} / \mathrm{L}$

$\mathrm{D}_{\mathrm{g}}=\left(\mathrm{L} \cdot \mathrm{D}^{2}\right)^{1 / 3}$

In these equations,

$\varnothing \quad$ : Sphericity (\%),

$\mathrm{D}_{\mathrm{g}} \quad$ : Geometric average diameter $(\mathrm{mm})$,

D : Diameter (mm),

L : Length (mm).

\subsubsection{Defining the grain volume}

Grain volume has been calculated in accordance with the weight of the fluid replaced by the grains placed into the liquid (toluene) [21,22]. With this purpose, 50 canola seed grains have been used in 3 repetitions and the average bulk density has been calculated.

\subsubsection{Defining the accumulation angle}

Cleaned seeds have been carefully placed inside a vertical cylinder and then slowly poured. The height and base diameter of the resulting cone shaped seed pile have been measured to calculate the accumulation angle by using the below relation. This has been repeated 24 times to determine the average accumulation angle $[23,24]$.

$\varnothing=\tan ^{-1}(2 \mathrm{H} / \mathrm{d})$

In this equation;

$\mathrm{H}$ : height (mm),

$\mathrm{d}$ : diameter value $(\mathrm{mm})$.

\subsubsection{Defining the friction coefficient:}

In order to determine the friction characteristics of the material on different surfaces, 3 different friction surfaces, galvanized metal, stainless steel and aluminium, have been used. Before conducting the friction test, the product should be skid sufficient times (50 times) on the friction surface, hence preparing the friction surface to the product [10].

For the purposes of defining the friction coefficient $\left(\mu_{s}\right)$ of the piled product, a dipping plated measurement device has been used. The dipping plated measurement device has a plate with an adjustable angle. In this mechanism, friction plate's inclination is increased until the moment the product starts to slide. The $(\Theta)$ tangent of the angle between the bed and the dipping plate has been taken as the friction coefficient. This procedure has been repeated 10 times to measure the required sliding heights for then to be able to move in 3 different friction plates. By using the sliding heights the friction coefficients in different friction materials have been found $[25,26]$.

$\mu_{\mathrm{s}}=\tan \Theta$

\section{Result and Discussion}

\subsection{Results Related to the Characteristics of Canola Plant}

As well as the harvesting method, canola harvesting is also affected by various generative characteristics such as stalk thickness of the plant, plant length, number of side branches, number of carobs etc. Therefore, the plant characteristics of the Elvis variety canola and field product yield have been defined after harvest at the trial field. The results related to these characteristics have been presented in Table 1.

Table 1. Value related to the plant characteristics of canola plant that has reached harvest maturity

\begin{tabular}{|l|r|}
\hline \multicolumn{1}{|c|}{ Properties } & \multicolumn{1}{c|}{$\begin{array}{c}\text { Average } \\
\text { Values }\end{array}$} \\
\hline Plant Stalk Diameter (mm) & $8.10 \pm 0,3$ \\
\hline Plant Length (cm) & $158.2 \pm 1,0$ \\
\hline Number of Side Branches (pcs) & $8.9 \pm 0,0$ \\
\hline Number of Grain (pcs) in Carob (capsule) & $27.1 \pm 2,0$ \\
\hline Number of Carob (capsule) (pcs) & $358.3 \pm 4,0$ \\
\hline Yield (kg/ha) & $3204 \pm 10$. \\
\hline
\end{tabular}

Reviewing some of the previous studies indicate that seed yield values have been calculated as $2593 \mathrm{~kg} / \mathrm{ha}$ [27], $2777 \mathrm{~kg} / \mathrm{ha}$ [28], $3097 \mathrm{~kg} / \mathrm{ha}$ [29], $2357 \mathrm{~kg} / \mathrm{ha} \mathrm{[30],} 2466$ $\mathrm{kg} / \mathrm{ha}$ [31] and $2180 \mathrm{~kg} / \mathrm{ha}$ [32]. Looking at these values, our yield value $(3204 \mathrm{~kg} / \mathrm{ha})$ seems to be very high. It is assumed that the reason for this seed yield value to be higher than those reported by other researchers is due to the variety characteristic of the seed and early planting period.

Plant stalk (trunk) thickness has been defined as 8.10 $\mathrm{mm}$, plant length as $158.2 \mathrm{~cm}$, number of side branch as 8,9 , number of carob per plant as 358.3 and number of grains per carob has been defined as 27.1. According to some studies related to winter canola; plant length values have been defined as $178.2 \mathrm{~cm}$ [33], $152.0 \mathrm{~cm}$ [34], 156.9 $\mathrm{cm}$ [32]. Number of side branches have been defined as 8.5 pcs. [35], 8.1 pcs [32] ; while number of grain in the carob have been defined as 28.0 pcs/carob [28] , 26.35 pcs /carob [36], 30 pcs /carob [32] and 25.3 pcs /carob [37]. Number of carobs in plant, on the other hand, have been defined as 336.0 pcs [38] and 338.7 pcs [32]. When we compare the values defined for plant in this study conducted under Kirklareli conditions, with the results of other studies, it can be said that the plant characteristics defined in other previous researches are in parallel to our data.

\subsection{Conclusions Related to Canola Seed's Harvest Related Features}

Moisture content related average of the canola seeds acquired from the trial zone during harvesting has been defined as $8.34 \%$ and product harvesting has been started on the assumption that sufficient moisture level required for harvesting has been reached. Some physical characteristics of the seed observed at $8.34 \%$ moisture content have been presented in Table 2. Looking at Table 


\section{INTERNATIONAL JOURNAL Of ENGINEERING TECHNOLOGIES}

\section{Mehmet Firat Baran et al., Vol.2, No.2, 2016}

2 ; the average length of the seed is $2.35 \mathrm{~mm}$, average diameter is $1.93 \mathrm{~mm}$, geometric average diameter 2.07 $\mathrm{mm}$, sphericity value 0.88 , single seed weight $0.0047 \mathrm{~g}$, thousand grain weight $4.74 \mathrm{~g}$, seed mass $5.07 \mathrm{~mm}^{3}$, volumetric weight $617 \mathrm{~kg} / \mathrm{m}^{3}$, accumulation angle is $29^{\circ}$, friction coefficient on galvanized metal surface is 0.318 , on stainless steel surface it is 0.288 , and on aluminium surface it is 0.305 .

Table 2. Some physical characteristics of canola seed measured at $8,4 \%$ moisture value

\begin{tabular}{|l|r|}
\hline \multicolumn{1}{|c|}{ Properties } & Average Values \\
\hline Length $(\mathrm{mm})$ & $2.35 \pm 0,20$ \\
\hline Width (diameter) $(\mathrm{mm})$ & $1.93 \pm 0,13$ \\
\hline Geometric Average Diameter $(\mathrm{mm})$ & $2.07 \pm 0,15$ \\
\hline Mass of single seed $(\mathrm{g})$ & $0.0047 \pm 0,0001$ \\
\hline 1000 grain weight $(\mathrm{g})$ & $4.74 \pm 0,15$ \\
\hline Sphericity $(\%)$ & $0.88 \pm 3,29$ \\
\hline Seed bulk density $\left(\mathrm{mm}^{3}\right)$ & $5.07 \pm 1,02$ \\
\hline Volumetric weight $\left(\mathrm{kg} / \mathrm{m}^{3}\right)$ & $617 \pm 2,2$ \\
\hline Accumulation angle $\left(^{0}\right)$ & $29 \pm 1,02$ \\
\hline $\begin{array}{l}\text { Friction coefficient } \\
(\text { Galvanized metal surface })\end{array}$ & $0.318 \pm 0,024$ \\
\hline $\begin{array}{l}\text { Friction coefficient } \\
(\text { Stainless steel surface })\end{array}$ & $0.288 \pm 0,018$ \\
\hline $\begin{array}{l}\text { Friction coefficient } \\
(\text { Aluminium surface })\end{array}$ & $0.305 \pm 0,012$ \\
\hline
\end{tabular}

The average sphericity value, calculated by using the length, width and thickness values of the canola seeds with an average moisture content of $8.34 \%$, is 0.88 . reviewing the results of similar studies conducted on canola seed, Razavi et al. ${ }^{[20]}$ reported that (2009), 4 different varieties of canola seed (Hyola, Okapi, Orient and SLM) in two different moisture level (5.27\%-23.69\%), depending on the variety, length values vary between 1.925-2.262 mm, diameter values between 1.475-1.911 mm, geometric average diameter values between 1.625-2.02 mm, while sphericity values vary between $0,82-0,93$. Çalışır et al ${ }^{[11]}$ reported that, 2005 under different moisture levels $(4.7 \%$, $13.14 \%, 23.96 \%)$, length values of canola seeds varied between 2.07-2.29 mm, diameter values between 1.84-1.99 $\mathrm{mm}$, geometric average diameter values between 1.91-2.08 $\mathrm{mm}$, and sphericity values varied between 0.93-091. Izli et $a l^{[12]}$ reported that (2009) performed similar measurements for 3 canola seed varieties (Capitol, Samurai and Jetneuf) under two different moisture content levels $(8.3 \%-25.9 \%$, $7.7 \%-27.4 \%, 7.3 \%-26.4 \%$ ) and for Capitol variety, length values varied between 2.46-2.57 $\mathrm{mm}$, diameter values between 1.96-2.08 mm, geometric average diameter values between $2.11-2.23 \mathrm{~mm}$, and sphericity values varied between $86.1 \%-86.8 \%$; while for Jetneuf variety; length values varied between 2.26-2.36 $\mathrm{mm}$, diameter values varied between 1.85-2.00 mm, geometric average diameter values varied between $1.98-2.12 \mathrm{~mm}$, and sphericity values varied between $87,4 \%-89,8 \%$. Following the study conducted on the Samurai variety, they have reported that the geometric characteristics have varied, even if very little; while the length values varied between 2.25-2.31 $\mathrm{mm}$, diameter values varied between 1.82-1.98 $\mathrm{mm}$, geometric average diameter values varied between 1.96$2.09 \mathrm{~mm}$, and sphericity values varied between $86.8 \%$ $89.6 \%$.

Looking at the results given in Table 2, we can say that the average 1000 seed mass of the canola seeds used in the study was $4.74 \mathrm{gr}$, while mass of single seed was 0.0047 gr. Similarly, Razavi et al ${ }^{[20]}$ reported that (2009) 1000 seed mass of the canola seed they have used in their study was 3.06-4.84 g; while Çalışır et al ${ }^{[11]}$ reported that (2005) the mass of single seed value as 0.0040-0.0065 gr.

According to Table 2, the seed volume is $5.07 \mathrm{~mm}^{3}$, while the volumetric mass has been calculated as 617 $\mathrm{kg} / \mathrm{m}^{3}$. Similarly, [20] reported that the volumetric mass of canola to be between $666,6-738,8 \mathrm{~kg} / \mathrm{m}^{3},[11]$ calculated it to be between $612.1-585.1 \mathrm{~kg} / \mathrm{m}^{3}$. [12] reported that depending on the variety, have reported the seed volume in capitol variety to be between $4.45-6.60 \mathrm{~mm}^{3}$, [13] have reported the seed volume to vary between $2.66 \mathrm{~mm}^{3}-6.44$ $\mathrm{mm}^{3}$.

Based on the results of the study, accumulation angle of the canola seed has been calculated as $29^{\circ}$. A similar result was reported by [20], where the accumulation angle value has been reported to vary between $25.37-28.54^{\circ}$.

Analysing the results related to friction coefficient, which is an important parameter in almost every postharvest works, it has been observed that Elvis variety canola seed displays different friction behaviours on different friction surfaces. The study has concluded that the lowest friction coefficient was on stainless steel surface by 0.288 . This value has been calculated as 0.305 on aluminium surface, while on galvanized metal surface, it has reached maximum value and was reported to be 0.318 . Similar findings have been reported by [20]. Researchers have calculated the friction coefficient as $0.301-0.419$ on galvanized metal, $0.260-0.414$ on fiberglass surface, and $0,358-0,450$ on carton surface. Based on the measurements conducted by [12] on galvanized metal surface, albeit depending on variety, they have reported that the friction coefficient values range between $0.244-0.358$. The closest value to the friction coefficient value of Elvis variety canola seed, used in our study, on galvanized metal has been observed in Capitol variety (0.314-0.358). On the other hand, friction coefficient values of Jetneuf (0.251$0.274)$ and Samurai $(0.244-0.272)$ varieties have proved to be very low.

\section{Conclusion}

In conclusion, when we compare the conclusions of this study with the data acquired in other studies, we see similarities in general, while the tiny differences between them are assumed to be related to the use of different canola seed varieties and the difference in moisture content of the seeds. The outcomes of this study, related to the plant and seed characteristics acquired during harvesting, shall be useful for the selection and designing of harvest machineries and the equipment to be used for post-harvest purposes for canola plant, which is being widely planted in Turkey. 


\section{INTERNATIONAL JOURNAL Of ENGINEERING TECHNOLOGIES}

Mehmet Firat Baran et al., Vol.2, No.2, 2016

\section{References}

[1] FAO, 2008. Production, Yield, Harvested Area Values of Rapeseed. Avaliable from FAOSTAT (April, 2010). www.fao.org.

[2] Süzer, S., 2008. Kanola Tarımı Kitabı. Hasad Yayıncilık.

[3] TUIK, 2008. Plant Production Techniques, (April 2010). www.tuik.gov.tr.

[4] Adolphe, D., 1987. Canola: The Universal Oilseed. $7^{\text {th }}$ International Rapeseed Congress, 11-14 May, PoznanPoland.

[5] Mailer, R.J., and Wratten, N., 1987. Glucosinolate Variability in Rapeseed in Australia. $7^{\text {th }}$ International Rapeseed Congress, 11-14 May, Poznan-Poland.

[6] Zukalova, H., Vasak, J., Fabry, A., 1985. Changes in the Quality Characteristics of Winter Rape Cultivars Free from Erucic and Glucosinolates. RostlinnaVyroba. $31: 685-692$.

[7] Baydar, H.,2005. Yield and Quality Characteristics of Canola Varieties in Isparta Conditions. S.D.Ü. Fen Bilimleri Enst. Dergisi,9-3(2005), Isparta.

[8] Röbbelen, G., Downey, R.K. and Ashri, A., 1989. Oilcrops of the World. McGraw Hill, USA.

[9] Weiss, E.A., 2000. Rapeseed. In: Oilseed Crops. Blackwell Sci. Ltd., Victoria, Australia.

[10] Kara, Turgut, N. ve M., 1999. Agricultural productsin Physical characteristic. Atatürk Üniversitesi Ziraat Fakültesi Ders Notları No: 212, Erzurum.

[11] Çalışır, S., Marakoğlu, T., Öğüt, H., and Öztürk, Ö., 2005. Physical Properties of Rapeseed. Journal of Food Engineering. 69:61-66.

[12] İzli, N., Ünal, H., and Sincik, M., 2009. Physical and Mechanical Properties of Rapeseed at Different Moisture Content. Institute of Agrophysics, Polish Academy of Sciences, .23:137-145.

[13] Hazbavi, I. and Minaei, S., 2009. Determination and Investigation of Some Physical Properties of Seven Variety Rapeseed. Iranian Journal of Food Science and Technology Winter. 5(4):21-28.

[14] Ülger, P., 1982. Buğday Hasat Harmanında Uygulanan Degişik Mekanizasyon Sistemlerinin Tane Ürün Kayıplarına Etkileri. Hasat Öncesi ve Hasat Sonrası Ürün Kayıpları Seminer Bildirileri, 13-17 Aralik p.: 195-243, Ankara

[15] Anonymous, 2009. Swathing, Combining "Harvest Management" http://www.canola.org/ chapter 11.aspx (26.01.2009)

[16] ASAE, 1997. ASAE S358.2, Moisture Measurement Unground Grain and Seed. In: ASAE 398 Standards, ASAE Press, St. Joseph. MI, USA.

[17] Şehirali, S., 1989. Seed Technology. Ders Kitab1, Ankara

[18] Önal, İ., 1995. Ekim Bakım Gübreleme Makinaları, E.Ü. Ziraat Fakültesi Yayınları No: 490, Bornova, İzmir.

[19] Mohsenin, N. N., 1970. Physical Properties of Plant and Animal Material. New York: Gordon and Breach Science Publishers.
[20] Razavi, S.M.A., Yeganehzad, S. and Sadeghi A., 2009. Moisture Dependent Physical Properties of Canola Seeds. J. Agric. Sci. Technol. 11:3009-322 .

[21] Lewis, M.J., 1996. Physical Properties of Foods and Food Processing Systems. Woodhead Publishing Limited, Cambridge, England

[22] Kayişoğlu, B. ve Esen, M., 2007. Ayçiçeği Tanesinin Nem Absorbsiyon Özelliklerinin Saptanması. Tekirdağ Ziraat Fakültesi Dergisi. 4 (2).

[23] Irtwange S.V., 2000. The Effect of Accession on Some Physical and Engineering Properties of African Yam Bean. Unpublished PhD Thesis, Department of Agricultural Engineering, University of Ibadan, Nigeria.

[24] Akaaimo D.I. and Raji A.O., 2006. Some Physical and Engineering Properties of Prosopis Africana seed. Bio systems Eng., 95(2):197-205.

[25] Kocabıyık, H., 1997. Ayçiçeğinin Hasada Yönelik Bazı Fiziksel ve Mekaniksel Özelliklerinin Saptanması Üzerine Bir Araştırma. Yüksek Lisans Tezi, T.Ü.Fen Bilimleri Enst. Tarım Makinaları Anabilim Dalı, 1997,Tekirdağ.

[26] Aktas T.; Celen, I. and Durgut, R., 2006. Some Physical and Mechanical Properties of Sunflower Seed (Carthamus tinctorius L.). Journal of Agronomy, 5 (4):613-616.

[27] Şaman, S., 1983. II. Ürün Tarımı Araştırma Yayım Projesi Rapeseed Dilimi, 1982-1983 Yılı Gelişme Raporu. T.C.T.O.K.B. Proje ve Uygulama Genel Müd., Antalya.

[28] Kolsarıc1, Ö. ve Er, C., 1988. Amasya İlinde Rapeseed Tarımında En Uygun Ekim Zamanı, Çeşit ve Bitki Sıklığı Tesbiti Üzerinde Araştırmalar. 2:163177.

[29] Başalma, D., 1999. The Effects of Different Planting Norms on Plant Characteristics and Yield and Quality of Winter Rapeseed Varieties. $3^{\text {rd }}$ Field Crops Congress, Turkey, 5-18 November, 317-322, Adana.

[30] Sağlam, C., Arslanoğlu, F. ve Kaba, S., 1999. Kışlık Rapeseed Çeşitlerinin Tekirdağ Koşullarına Adaptasyonu. $3^{\text {rd }}$ Field Crops Congress, Turkey, 5-18 November, p:344-347, Adana.

[31] Karaaslan, D., 1999. Diyarbakır Koşullarında Yetiştirilebilecek Rapeseed Çeşitlerinin Saptanması Üzerine Bir Araştırma. $3^{\text {rd }}$ Field Crops Congress, Turkey, 5-18 November, 328-333, Adana.

[32] Öz, M., 2002. Bursa Mustafakemalpaşa Koşullarında Different Ekim Zamanlarının Kışlık Rapeseed Çeşitlerinde Verim ve Bazı Verim Unsurları Üzerine Olan Etkileri. Uludağ Üniv. Zir. Fak. Dergisi. 16: 113.

[33] Kolsarıc1, Ö. ve Başoğlu, F., 1984. Yağ Kalitesi ve Yağ Oranı Yüksek Kışlık Rapeseed Çeşit ve Hatlarının Verim Komponentleri Yönünden Karşılaştırılması. A.Ü. Ziraat Fakültesi Yıllığı, s.6676.

[34] Raymer, P.L., Bullock, D.G. and Thomas, D.L., 1990. Potential of Winter and Spring Rapeseed Cultivars for Oilseed Production in the Southern United States, s:223-225, Timber Press. 
INTERNATIONAL JOURNAL Of ENGINEERING TECHNOLOGIES

Mehmet Firat Baran et al., Vol.2, No.2, 2016

[35] Karacaoğlu, N., Kaya, Ç. ve Çiçek, N., 1998. Canola Araştırmaları. T. O. K. B. Ege Agricultural Araştırma Enstitüsü, İzmir.

[36] Kolsarıc1, Ö. ve Er, C., Tarman, D., 1985. Islah Edilmiş Kışlık Rapeseed Çeşitlerinde Verim Komponentlerinin Karşılaştırılması. A.Ü. Ziraat Fakültesi Yıllığ1, 61-74.

[37] Göksoy, A.T. ve Turan, Z.M., 1986. Studies on Yield and Quality Characteristics of Certain Rapeseed Varieties. U. Ü. Ziraat Fakültesi Dergisi. 5: 75-83.

[38] İlisulu, K., 1970. Adaptation, Seed Yields and Other Characteristics of Rapeseed Varieties, Brought from France and Germany, under Ankara Climate and Soil Conditions. A.Ü. Z.F. Yıllığı, s.132-157. 